\title{
Mitochondrial DNA and TFAM gene variation in early-onset myocardial infarction: evidence for an association to haplogroup $\mathrm{H}$.
}

María Palacín ${ }^{\mathrm{a}}$, Victoria Alvarez ${ }^{\mathrm{a}, \mathrm{g}}$, María Martín ${ }^{\mathrm{b}}$, Marta Díaz ${ }^{\mathrm{a}}$, Ana I. Corao ${ }^{\mathrm{a}}$, Belén Alonso $^{\mathrm{a}}$, Beatriz Díaz-Molina ${ }^{\mathrm{b}}$, Iñigo Lozano ${ }^{\mathrm{b}}$, Pablo Avanzas ${ }^{\mathrm{b}}$, César Morís ${ }^{\mathrm{b}}$, Julián R. Reguero $^{\text {b, Isabel Rodríguez }}{ }^{\mathrm{c}, \mathrm{g}}$, Carlos López-Larrea ${ }^{\mathrm{d}, \mathrm{g}}$, Jorge Cannata-Andía ${ }^{\mathrm{c}, \mathrm{g}, \mathrm{h}}$, Alberto Batalla $^{\mathrm{e}}$, Marta Ruiz-Ortega ${ }^{\mathrm{f}, \mathrm{g}}$, Pablo Martínez-Camblor ${ }^{\mathrm{i}}$, Eliecer Coto ${ }^{\mathrm{a}, \mathrm{g}, \mathrm{h}}$

${ }^{a}$ Genética Molecular, ${ }^{\mathrm{b}}$ Cardiología, ${ }^{\mathrm{c}}$ Bone and Mineral Research Unit, and ${ }^{\mathrm{d}}$ Inmunología, Hospital Universitario Central de Asturias, Oviedo, Spain.

e Cardiología, Hospital Cabueñes, Gijón, Spain.

f Cellular Biology in Renal Diseases Laboratory, Fundación Jiménez Díaz and Universidad Autónoma de Madrid, Spain.

${ }^{\mathrm{g}}$ Red de Investigación Renal-REDINREN and ${ }^{\mathrm{f}}$ Instituto Reina Sofía de Investigación Nefrológica, Spain.

${ }^{\mathrm{h}}$ Department Medicine, University Oviedo, Oviedo, Spain

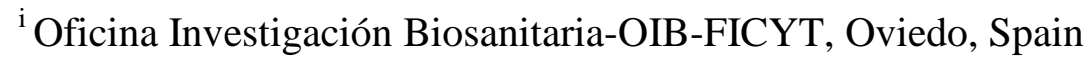

\section{Correspondence:}

Eliecer Coto,PhD

Genética Molecular

Hospital Central Asturias-Maternidad

33006-Oviedo-SPAIN

Email: eliecer.coto@sespa.princast.es

Keywords: atherosclerosis; myocardial infarction; mitochondria; haplogroups; mitochondrial transcription factor.

Short title: mitochondrial DNA variants in myocardial infarction.

Conflict of interests. The authors declare they did not have conflict of interests related to this work. 


\begin{abstract}
The main objective of this research was to define the association between common mitochondrial DNA (mtDNA) polymorphisms and mitochondrial transcription A gene (TFAM) variants and myocardial infarction (MI) in patients with atherosclerotic diseased vessels. Ten mitochondrial polymorphisms that defined the nine common European haplogroups were genotyped in 500 male patients with early onset MI ( $<55$ years) and at least one atherosclerotic coronary vessel (angiographically confirmed), and 500 healthy controls. In addition, we searched for DNA variants in the coding region of the TFAM gene and compared patients and controls for the allele and genotype frequencies.

Early onset MI was strongly associated with male gender and tobacco smoking in our population. MtDNA haplogroup $\mathrm{H}$ (defined by allele $7028 \mathrm{C}$ ) was significantly more frequent in a first group of patients $(n=250)$ compared to controls $(n=300)$, and the association was confirmed in a second group of only smokers (250 patients and 200 controls). For total patients and controls, we obtained a $\mathrm{p}=0.002(\mathrm{OR}=1.50 ; 95 \% \mathrm{CI}=1.17$ 1.92) for $\mathrm{H}$ vs. the other haplogroups. We found four common TFAM polymorphisms, with allele/genotype frequencies that did not differ between patients and controls.

In conclusion, mitochondrial haplogroup $\mathrm{H}$ was associated with early onset $\mathrm{MI}$ in male smokers. Our work supported a role for the mtDNA variation in the risk for atherosclerosis and ischemic associated events, likely due to differences in mitochondrial function and reactive oxygen production between the different haplogroups.
\end{abstract}




\section{Introduction}

Mitochondria are the cellular organelles where energy is produced in the form of ATP. As a result of this process reactive oxygen species (ROS) are produced, and these ROS need to be neutralized to avoid extensive cellular damage and senescence. Increased mitochondrial ROS production has been linked to vascular smooth muscle cells (VSMCs) dysfunction, rendering an endothelium vulnerable to the development of atherosclerotic lesions and plaque rupture. A number of cardiovascular risk factors would induce the overproduction of ROS, contributing to the atherosclerotic process. In the last years, several works explained the pro-atherogenic effect of the main cardiovascular risk factors (hyperglycemia, dyslipemia, cigarrette smoking) in terms of mitochondrial dysfunction (Ross 1995; Ballinger et al., 2002; Sorescu et al., 2002; Madamanchi et al., 2007).

Mitochondria contain their own DNA (mtDNA) in a single circular chromosome and their own transcription and translation machinery. The mtDNA is inherited from the mother and contains the genes for 13 units of the electron transfer chain, 22 tRNAs, and 2 rRNAs. More than 75 human diseases have been associated with rare mutatitons in the mitochondrial genome (DiMauro et al., 2003). In addition, the mtDNA sequence is highly polymorphic and this variation accumulated sequentially along female lineages. Nine haplogroups defined by mtDNA single nucleotide polymorphisms (SNPs) are commonly used to classify the individuals of European ancestry (Torroni et al., 1996; Ruiz-Pesini et al., 2004; Booker et al., 2006). These haplogroups have been associated with the risk of developing common diseases, such as Parkinson's and Alzheimer's disease, ischemic stroke, coronary artery disease, cardiac hypertrophy, and several types of cancer (van der Walt et al., 2003; van der Walt et al., 2004; Gaweda-Walerych et al., 2008). These effects on disease susceptibility could be explained by differences between the haplogroups on the efficiency of oxygen consumption and ATP and ROS production (Ruiz-Pesini et al., 2000; Castro et al., 2006; Kofler et al., 2009; MartinezRedondo et al., 2010).

The mitochondrial transcription factor A (encoded by a nuclear gene, TFAM) plays a major role in mtDNA copy number and transcription (Larsson et al., 1998; Kang et al., 2007). The number of copies of mtDNA is directly dependent on the levels of mtTFA, with mice heterozygous for a tfam deletion showing a significant reduction in mtDNA copies (Ekstrand et al., 2004). MtDNA transcripts were upregulated in VSMCs from rats exposed to cigarette smoke, that showed a 
phenotype characteristic of experimentally induced atherogenesis (Masayesva et al., 2006). Conditional heart deletion of tfam reproduced in mice the pathophysiological features of mitochondrial cardiomyopathy, with a significant reduction of mtDNA copies in cardiomyocytes and a reduction in respitarory chain activity (Wang et al., 1999; Li et al., 2000; Kanazawa et al., 2002). Overexpression of tfam ameliorated mitochondrial deficiencies in postinfarction mice, inhibiting left ventricular remodeling (Russell et al., 2004; Ikeuchi et al., 2005).

We hypothesised that variation at the mtDNA and TFAM could regulate the risk of developing atherosclerosis and suffering ischemic associated episodes. Therefore, we analyzed the association between mtDNA and TFAM variants and early onset myocardial infarction. 


\section{Methods.}

\subsection{Patients and controls.}

The study had two phases: in a first set of patients and controls (the index cohort; recruited in the period 1996-2001) we determined the association between early onset myocardial infarction (EOMI) and mitochondrial haplogroups and TFAM variants; significant associations were replicated in a second cohort of patients and controls (recruited in the period 2001-2006). They were recruited for a research project to characterize the genetic variation that contributed to EOMI (Alvarez et al., 1998; Batalla et al., 2000; Gonzalez et al., 2006).

Because $<10 \%$ of the EOMI cases who attended our Cardiology Department were women, only male patients were included in the study. All them had suffered a first episode of MI, defined according to the WHO MONICA (Multinational Monitoring of trends and determinants in Cardiovascular disease) (Tunstall-Pedoe et al., 1994). All the patients underwent coronary angiography for diagnostic purposes, and only those who had at least one atherosclerotic diseased coronary vessel (luminal narrowing > 70\%) were included in the study.

Controls were hospital staff, eligible residents, and blood bank donors, and were matched with patients for age and ethnicity. None of them had episodes of cardiovascular disease. Table 1 summarizes the main characteristics of patients and controls. All the patients and controls were Caucasians from the region of Asturias (Northern Spain; total population 1 million), and gave their informed consent to participate in the study, approved by the Ethical Committee of Hospital Central Asturias.

\subsection{Definition of the analytical parameters.}

Blood was obtained from the patients during hospitalization and their analytical profile was determined. Patients and controls were defined as hypertensives if they had a documented history of hypertension, were receiving antihypertensive drugs, or had a systolic blood pressure $>140$ $\mathrm{mmHg}$ and/or a diastolic blood pressure $>90 \mathrm{mmHg}$. Individuals with a clinical history of diabetes mellitus, who were using antidiabetic drugs, or who had a fasting blood glucosa level $>15 \mathrm{mmol} / \mathrm{L}$ in more than two determinations were considered as diabetics. Patients and controls with a clinical history of hypercholesterolaemia, who were receving lipid lowering drugs, or who had fasting total colesterol $>250 \mathrm{mg} / \mathrm{dL}$ were classified as hypercholesterolaemics. Current cigarette smokers were considered as smokers. 


\subsection{Haplogroups classification.}

A total of $10 \mathrm{mtDNA}$ SNPs were determined in all the patients and controls. Briefly, DNA was obtained from $10 \mathrm{ml}$ of blood and polymerase chain reaction (PCR) amplified as reported (Huerta et al., 2005). PCR fragments were digested with the appropriated restriction enzyme, and electrophoresed on 3\% agarose gels to visualise the alleles (suppl. Table 1; suppl. Fig 1). The nine haplogroups were defined by the nucleotides at the 10 polymorphic sites (see the mitomap database for haplogroups definition; www.mitomap.org) (suppl. Table 2). Patients and controls who were classified as $\mathrm{H}$ were further subdivided into $\mathrm{H} 1$ and non- $\mathrm{H} 1$ by the allele at position 3010 ( $\mathrm{A}=\mathrm{H} 1 ; \mathrm{G}=$ non-H1) (suppl. Table 1).

\subsection{TFAM sequence variation.}

The search for DNA variants in the TFAM gene was performed in the index cohort. The seven coding exons were PCR-amplified in fragments 180 to $327 \mathrm{bp}$ long with primers that matched the flanking introns (suppl. Table 3). To search for sequence variants, the PCR fragments from 250 patients and 250 controls were subjected to single strand conformation analysis (SSCA) and denaturing high performance liquid chromatography (DHPLC), as reported (Alonso-Montes et al., 2008). To characterise the nucleotide changes, PCR fragments representative of the different SSCA-electrophoretic or DHPLC-elution patterns were sequenced using BigDye chemistry in an automated ABI310 capillary system (Applied Biosystems, Foster City, CA, USA) (suppl. Fig 2). The G/C exon 1 polymorphism (rs1937; S12T) affected a site for the restriction enzyme DdeI. This SNP was genotyped in 400 patients and 450 controls through digestion with the restriction enzyme DdeI of a PCR-fragment amplified with primers for exon 1 (suppl. table 3). After electrophoresis on $3 \%$ agarose gels, the two alleles were visualized as bands of $326 \mathrm{bp}$ (allele C) and $200+126$ bp (allele G).

\subsection{Statistical analysis.}

Frequencies for the non-continous variables (alleles and haplogroups) between patients and controls were compared through the $\chi^{2}$ or the Fisher's exact probability tests. Odds ratios (ORs) and their $95 \%$ confidence intervals (CIs) were also calculated. We compared each haplogroup frequency with the frequency of all other haplogroups pooled into one group (van der Walt et al., 2003; van der Walt et al., 2004; Gaweda-Walerych et al., 2008). A p<0.05 was considered as the level of statistical significance. The Student's t-test was used to compare the difference in means between the groups. Logistic regression was used to determine the association of haplogroup 
with EOMI after correcting by covariates (age, BMI, diabetes, cholesterol, hypertension). All statistical analyses were performed with the SPSS statistical package (v.11.0).

\section{Results.}

\subsection{EOMI and classical risk factors.}

The main characteristics of MI patients and controls are summarized in Table 1. Early onset MI was strongly associated with male gender and cigarette smoking in our index cohort $(\mathrm{p}<0.001)$. We also found significantly higher frequencies of hypertensives $(\mathrm{p}<0.001)$, diabetics $(\mathrm{p}=0.044)$, and hypercholesterolaemics $(\mathrm{p}=0.036)$ among the index patients.

\subsection{Mt haplogroup frequencies.}

Haplogroup $\mathrm{H}$ was significantly more frequent among the patients in the index cohort $(\mathrm{p}=0.03$; $\mathrm{OR}=1.44$, 95\% CI=1.03-2.02) (Table 2). In the replication study, haplogroup $\mathrm{H}$ was also significantly more frequent among the patients $(\mathrm{p}=0.02 ; \mathrm{OR}=1.58,95 \% \mathrm{CI}=1.09-2.30)$. Considering the H-frequencies in the index cohort, a total of 480 patients and 480 controls should be required to reach a statistical power of 80 . We pooled all the patients $(n=500)$ and controls $(\mathrm{n}=500)$ and obtained a $\mathrm{p}=0.002$ for $\mathrm{H}$ vs. non- $\mathrm{H}(\mathrm{OR}=1.50 ; 95 \% \mathrm{CI}=1.17-1.92)$, with a power (\% of detecting a difference) of 89 . This difference remained significant when only smoker patients $(H=50 \%, 244 / 487)$ and controls $(H=37 \%, 99 / 267)$ were compared $(p=0.0004$; $\mathrm{OR}=1.70$, 95\% CI=1.25-2.31) (suppl. Table 4). Haplogroup $\mathrm{H}$ also remained significantly associated after correcting for total cholesterol $(\mathrm{p}=0.022)$, hypertension $(\mathrm{p}=0.049)$, and tryglicerides $(\mathrm{p}=0.045)$.

We determined the frequencies of subhaplogroup H1, characterized by allele 3010A. Among $\mathrm{H}$ individuals, the frequency of 3010A carriers was higher in controls (32\%) than in patients (29\%), a non-significant difference. A total of 181 of the patients (36\%) were non-H1 compared to 127 of the controls (27\%). Thus, the difference in $\mathrm{H}$ frequency between the two groups could be mainly attributed to an excess of non-H1 among the patients $(\mathrm{p}=0.003 ; \mathrm{OR}=1.50,95 \% \mathrm{CI}=1.15$ 1.97). 


\subsection{TFAM variation.}

We investigated the variation in TFAM and we found a total of four previously reported variants, two in the coding (rs1937, rs 17710934) and two (rs34084383, rs41283688) in the intronic flanking sequence (table 3). Genotype frequencies did not differ from those expected under the Hardy-Weinberg equilibrium in both, patients and controls. We did not find rare sequence variants in the patients that could explain an increased risk for EOMI. In addition, none of the four common variants was significantly associated with EOMI. We also examined the interaction between the four TFAM variants and haplogroup $\mathrm{H}$ on EOMI risk. Genotype and allele frequencies did not differ between patients and controls for the four polymorphisms (suppl. table 5). Together, these data indicated that TFAM variation did not contribute to the risk for EOMI MI in our population. However, we used SSCA and DHPLC for searching TFAM variants, two techniques with an estimated rate for false negatives of approximately 5\%. We cannot thus exclude that some TFAM variants were not detected in our patients/controls. 


\section{Discussion.}

We found a significantly higher frequency of mitochondrial haplogroup H among EOMI patients. This haplogroup was previously associated with some traits. For instance, riboflavin was more effective in non-H patients with migraine, and effect that could result from an increased activity of complex I (the main target of riboflavin) among $\mathrm{H}$ individuals (Di Lorenzo et al., 2009). Haplogroup H was also associated $(\mathrm{p}=0.007)$ with increased lipoatrophy among AIDS patients receiving nucleoside reverse transcriptase inhibitors (Hendrickson et al., 2009). This haplogroup has been linked to an increased survival after sepsis (Baudouin et al., 2005). This advantage could be partly explained by the fact that $\mathrm{H}$-individuals had higher maximum temperatures, being fever a basic mechanism to combat infection. A higher resistance to infections compared to other haplogroups could also explain why $\mathrm{H}$ is the most common European haplogroup in spite of being the most recent (Herrnstadt et al., 2004). Haplogroup H was defined by a SNP at position 7028, a synonymous change in the cytochrome c oxidase subunit I (COI) of the mitochondrial complex IV. To define the mtDNA functional variants that could explain its association to EOMI and the other traits would require the sequencing of the whole mtDNA in H-patients.

Higher ROS production among haplogroup $\mathrm{H}$ cells could result in an increased endothelial dysfunction, predisposing to the development of atherosclerotic lesions in response to injuries such as compounds from cigarette smoke (Miro et al., 1999; Ballinger et al., 2002; Masayesva et al., 2006). Martinez-Redondo et al. reported higher maximum oxygen compsumption $\left(\mathrm{VO}_{2 \max }\right.$ in response to exercise among H-individuals (Martinez-Redondo et al., 2010). A positive correlation of $\mathrm{H}$ with electron transport chain coupling and increased ATP and ROS production was supported by the finding of higher intracellular ATP concentrations in Huntington's disease patients carrying the 7028C allele (Arning et al., 2010). However, at least one study did not find functionally-important bioenergetic differences between mitochondria bearing $\mathrm{H}$ and other haplogroups (Amo et al., 2008).

The association between mtDNA variants and ischemic diseases has been previously studied by others (Abu-Amero et al., 2009; Nishigaki et al., 2007; Benn et al., 2008; Rosa et al., 2008; Kofler et al., 2009). Rosa et al. reported a higher frequency of 7028C among Portuguese patients with ischemic stroke vs. controls (Rosa et al., 2008). This was in agreement with the significant association between haplogroup $\mathrm{H}$ and EOMI. Kofler et al. found a higher frequency of 
haplogroup T among coronary artery disease patients from Austria (Kofler et al., 2009). We did not find this difference, although we had reported a significant association between haplogroup $\mathrm{T}$ and cardiac hypertrophy (Castro et al., 2006). An association of mtDNA variation with MI was also reported among Japanese, a population with a different haplogroups structure (Nishigaki et al., 2007).

A recent study by Benn et al. did not support an association of mitochondrial haplogroups with risk of ischemic cardiovascular disease among Danish (Benn et al., 2008). The frequency of haplogroup $\mathrm{H}$ was $45.9 \%$, and hazard ratios for hospitalization due to all cardiovascular disorders, ischemic heart disease, ischemic cerebrovascular disease, and death from all causes did not differ between the haplogroups. The difference remained non-significant after stratification by major causes of cardiovascular disease. An explanation for these discrepancies between studies is that they were based on populations from different regions, and there is a heterogenous geographical distribution of mtDNA haplogroups. Therefore, our study on a region from Spain region cannot be directly compared with other Northern European populations.

Our work has several limitations. It was based on patients with early onset myocardial infarction, a group in which genetic predisposing factors should be more relevant (compared to elderly patients) (Kathiresan et al., 2009). It was also based on only male patients who survived a first MI episode, and we could thus not exclude an association with MI in women or with fatal MI. Also, we included only patients <55 years, were smokers, and had atherosclerotic diseased vessels. Other studies included also women and individuals $>55$ years, $<50 \%$ were smokers, and the presence of angiographicaly documented CAD (stenosis $>50 \%$ in at least one coronary vessel) was not an inclusion criteria. A significant proportion of our controls were recruited through a blood bank, that could result in a bias toward healthier individuals (compared to controls recruited from the general population). The frequency of diabetics, hypertesnsives, and hypercholesterolaemics could thus be underestimated in our controls. However, we think this would not affect the results because the frequency of diabetics, hypercholesterolaemics, and hypertensives among these controls were almost identical to the reported prevalence of these manifestations in the general population from Spain (Valdes et al., 2007). In addition, haplogroup frequencies did not differ between the main clinical subgroups in patients and controls. 
Finally, we searched for DNA variants in the TFAM gene in our patients and controls. TFAM is a nuclear gene that encodes the mitochondrial transcription factor, and TFAM functional variants could result in differences in mtDNA transcription and replication, two processes that have been found altered in several diseases. In addition, some TFAM polymorphisms have been linked to the risk of developing Alzheimer's and Parkinson's, two diseases in which mitochondrial dysfunction plays a major role [Alvarez et al. 2008; Belin et al. 2007; Gaweda-Walerych et al. 2010]. We only found four common TFAM variants, with allele and genotype frequencies that did not differ between patients and controls. In addition, these frequencies did not differ between patients and controls who were haplogroup $\mathrm{H}$ and non- $\mathrm{H}$ in both, patients and controls . Together, these data suggested that TFAM variation did not contribute to the risk for EOMI in our population.

In summary, we described a significant higher risk for early onset MI in male with mitochondrial haplogroup H. This association was based on patients who were smoker and had atherosclerotic vessels, and could be caused by a higher mitochondrial dysfunction and ROS production in response to cigarette smoke among carriers of this haplogroup.

Acknowledgements. This work was supported by grants from the Spanish Fondo de Investigaciones Sanitarias-Fondos FEDER European Union (FIS-06/0214; 09-00172), and Red de Investigación Renal-REDINREN (RD06/0016). MP is the recipient of a predoctoral fellowship from FICYT.

Disclosures. All the authors declare they have no conflict of interest related to this work. 
Table 1. Main characteristics of patients and controls in the first and second (replication) cohorts, and the total patients and controls.

\begin{tabular}{|c|c|c|c|c|c|c|c|}
\hline & $\begin{array}{c}\text { Index } \\
\text { Patients } \\
(\mathbf{n = 2 5 0})\end{array}$ & $\begin{array}{c}\text { Index } \\
\text { Controls } \\
(\mathbf{n = 3 0 0})\end{array}$ & $\begin{array}{c}\text { Replication } \\
\text { patients } \\
(\mathbf{n = 2 5 0})\end{array}$ & $\begin{array}{c}\text { Replication } \\
\text { controls } \\
(\mathbf{n = 2 0 0})\end{array}$ & $\begin{array}{c}\text { Total } \\
\text { patients } \\
(\mathbf{n = 5 0 0})\end{array}$ & $\begin{array}{c}\text { Total } \\
\text { controls } \\
(\mathbf{n = 5 0 0})\end{array}$ & $\begin{array}{c}\mathbf{p} \\
\text { value }\end{array}$ \\
\hline $\begin{array}{c}\text { Mean age } \\
\text { (years) }\end{array}$ & $43 \pm 5$ & $44 \pm 8$ & $45 \pm 5$ & $47 \pm 7$ & $44 \pm 7$ & $45 \pm 7$ & 0.06 \\
\hline $\begin{array}{c}\text { Range } \\
\text { (years) }\end{array}$ & $25-55$ & $18-60$ & $26-55$ & $18-60$ & $25-55$ & $18-60$ & \\
\hline $\begin{array}{c}\text { Smokers (\%) } \\
\text { (237 }\end{array}$ & 117 & 250 & 150 & 487 & 267 & $<0.001$ \\
\hline $\begin{array}{c}\text { Total Chol } \\
(\mathrm{mg} / \mathrm{dl})\end{array}$ & $220 \pm 55$ & $195 \pm 40$ & $222 \pm 56$ & $197 \pm 42$ & $222 \pm 45$ & $195 \pm 39$ & $<0.001$ \\
\hline HDL (mg/dl) & $30 \pm 10$ & $49 \pm 11$ & $33 \pm 9$ & $51 \pm 12$ & $32 \pm 10$ & $50 \pm 10$ & $<0.001$ \\
\hline TG (mg/dl) & $162(94)$ & $106(80)$ & $161(95)$ & $109(81)$ & $162(94)$ & $107(79)$ & $<0.001$ \\
\hline Hyperchol. & $18 \%$ & $12 \%$ & $18 \%$ & $13 \%$ & $18 \%$ & $12 \%$ & 0.036 \\
\hline Hypertens. & $35 \%$ & $11 \%$ & $36 \%$ & $12 \%$ & $36 \%$ & $11 \%$ & $<0.001$ \\
\hline Diabetes & $12 \%$ & $7 \%$ & $9 \%$ & $5 \%$ & $12 \%$ & $6 \%$ & 0.044 \\
\hline & & & & & & & \\
\hline
\end{tabular}


Table 2. Distribution of the nine mitochondrial haplogroups in patients with early onset myocardial infarction and healthy controls (in parenthesis, \%).

\section{$\underline{\text { Index cohort }} \underline{\text { Replication cohort }} \quad \underline{\text { Total }}$}

\begin{tabular}{|c|c|c|c|c|c|c|}
\hline Haplogroup & $\begin{array}{c}\text { Patients } \\
(\mathrm{n}=250)\end{array}$ & $\begin{array}{c}\text { Controls } \\
(\mathrm{n}=300)\end{array}$ & $\begin{array}{c}\text { Patients } \\
(\mathrm{n}=250)\end{array}$ & $\begin{array}{c}\text { Controls } \\
(\mathrm{n}=200)\end{array}$ & $\begin{array}{c}\text { Patients } \\
(\mathrm{n}=500)\end{array}$ & $\begin{array}{c}\text { Controls } \\
(\mathrm{n}=500)\end{array}$ \\
\hline $\mathrm{H}$ & $125(50)$ & $123(41)$ & $127(51)$ & $79(40)$ & $252(50)$ & $202(40)$ \\
$\mathrm{H} 1$ & $36(15)$ & $39(13)$ & $35(14)$ & $26(13)$ & $71(14)$ & $65(13)$ \\
Non-H1 & $89(35)$ & $84(28)$ & $92(37)$ & $53(27)$ & $181(36)$ & $137(27)$ \\
\hline $\mathrm{I}$ & $2(1)$ & $3(1)$ & 0 & $3(1)$ & $2(<1)$ & $6(1)$ \\
\hline $\mathrm{J}$ & $28(11)$ & $45(15)$ & $28(11)$ & $29(14)$ & $56(11)$ & $74(15)$ \\
\hline $\mathrm{K}$ & $10(4)$ & $24(8)$ & $10(4)$ & $19(9)$ & $20(4)$ & $43(9)$ \\
\hline $\mathrm{T}$ & $30(12)$ & $27(9)$ & $24(10)$ & $16(8)$ & $54(11)$ & $43(9)$ \\
\hline $\mathrm{U}$ & $24(10)$ & $37(12)$ & $30(12)$ & $25(13)$ & $54(11)$ & $62(12)$ \\
\hline $\mathrm{V}$ & $11(4)$ & $15(5)$ & $12(5)$ & $14(7)$ & $23(5)$ & $29(6)$ \\
\hline $\mathrm{W}$ & $5(2)$ & $9(3)$ & $6(2)$ & $6(3)$ & $11(2)$ & $15(3)$ \\
\hline $\mathrm{X}$ & $2(1)$ & $5(2)$ & $2(1)$ & $3(2)$ & $4(<1)$ & $8(1)$ \\
\hline other & $13(3)$ & $12(4)$ & $11(4)$ & $6(3)$ & $24(5)$ & $18(4)$ \\
\hline
\end{tabular}

$\mathrm{p}=0.03 ; \mathrm{OR}=1.44(1.03-2.02) \mathrm{H}$ vs. nonH, first group. $\mathrm{p}=0.02 ; \mathrm{OR}=1.58(1.09-2.30) \mathrm{H}$ vs. nonH, $2^{\text {nd }}$ group. $\mathrm{p}=0.002 ; \mathrm{OR}=1.50(1.17-1.92) \mathrm{H}$ vs. nonH, total patients vs controls $\mathrm{p}=0.003 ; \mathrm{OR}=1.50(1.15-1.97)$ nonH1 vs. the other haplogroups, total patients vs. controls. 
Table 3. Genotype and allele frequencies for the TFAM gene variants in patients and controls (parenthesis indicates \%).

\begin{tabular}{|c|c|c|c|}
\hline Polymorphism $^{a}$ & $\begin{array}{c}\text { Genotypes/ } \\
\text { alelles }\end{array}$ & $\begin{array}{c}\text { Patients } \\
(\%)\end{array}$ & $\begin{array}{c}\text { Controls } \\
(\%)\end{array}$ \\
\hline \multirow{5}{*}{$\begin{array}{c}\mathbf{r s 1 9 3 7} \\
+35 \mathrm{C} / \mathrm{G}(\mathrm{S} 12 \mathrm{~T})\end{array}$} & GG & $352(88)$ & $407(90)$ \\
\hline & $\mathrm{GC}$ & $44(11)$ & $40(10)$ \\
\hline & $\mathrm{CC}$ & $4(1)$ & $3(<1)$ \\
\hline & $G$ & 0.94 & 0.94 \\
\hline & $\mathrm{C}$ & 0.06 & 0.06 \\
\hline \multirow{5}{*}{$\begin{array}{c}\text { rs17710934 } \\
+183 \mathrm{~T} / \mathrm{C} \\
(\mathrm{S} 61 \mathrm{~S})\end{array}$} & TT & $241(96)$ & $225(94)$ \\
\hline & $\mathrm{TC}$ & $9(4)$ & $25(6)$ \\
\hline & $\mathrm{CC}$ & 0 & 0 \\
\hline & $\mathrm{T}$ & 0.98 & 0.95 \\
\hline & $\mathrm{C}$ & 0.02 & 0.05 \\
\hline \multirow{5}{*}{$\begin{array}{c}\text { rs34084383 } \\
\text { IVS3-13 } \\
\text { del/insT }\end{array}$} & Ins/ins & $2(1)$ & $5(2)$ \\
\hline & Ins/del & $65(26)$ & $75(30)$ \\
\hline & Del/del & $183(73)$ & $170(68)$ \\
\hline & Ins & 0.14 & 0.17 \\
\hline & Del & 0.86 & 0.83 \\
\hline \multirow{5}{*}{$\begin{array}{c}\text { rs41283688 } \\
\text { IVS6 +11G/A }\end{array}$} & GG & $215(86)$ & $205(81)$ \\
\hline & GA & $32(11)$ & $43(17)$ \\
\hline & AA & $3(3)$ & $2(2)$ \\
\hline & $G$ & 0.92 & 0.91 \\
\hline & $\mathrm{A}$ & 0.08 & 0.09 \\
\hline
\end{tabular}

a genotype and allele frequencies for rs17710934, rs34084383, and rs41283688 were derived from 250 patients and 250 controls; for the rs 1937 from 400 patients and 450 controls. Allele and genotype frequencies for the four polymorphisms did not differ between the two groups (Fisher's exact test, $\mathrm{p}>0.05$ ). 


\section{References.}

Abu-Amero, K. K., Al-Boudari, O. M., Mousa, A., Gonzalez, A. M., Larruga, J. M., Cabrera, V. M. and Dzimiri, N. (2010). The mitochondrial DNA variant $16189 \mathrm{~T}>\mathrm{C}$ is associated with coronary artery disease and myocardial infarction in Saudi Arabs. Genet Test Mol Biomarkers 14, 43-47.

Alonso-Montes, C., Castro, M. G., Reguero, J. R., Perrot, A., Ozcelik, C., Geier, C., Posch, M. G., Moris, C., Alvarez, V., Ruiz-Ortega, M. and Coto, E. (2008). Mitochondrial transcription factors TFA, TFB1 and TFB2: a search for DNA variants/haplotypes and the risk of cardiac hypertrophy. Dis Markers 25, 131-139.

Alvarez, R., Reguero, J. R., Batalla, A., Iglesias-Cubero, G., Cortina, A., Alvarez, V. and Coto, E. (1998). Angiotensin-converting enzyme and angiotensin II receptor 1 polymorphisms: association with early coronary disease. Cardiovasc Res 40, 375-379.

Alvarez, V., Corao, A.I., Sanchez-Ferrero, E., De Mena, L., Alonso-Montes, C., Huerta, C., Blazquez, M., Ribacoba, R., Guisasola, L.M., Salvador, C., Garcia-Castro, M., and Coto, E. (2008). Mitochondrial transcription factor A (TFAM) gene variation in Parkinson's disease, Neurosci. Lett. 432, 79-82.

Amo, T., Yadava, N., Oh, R., Nicholls, D. G. and Brand, M. D. (2008). Experimental assessment of bioenergetic differences caused by the common European mitochondrial DNA haplogroups H and T. Gene 411, 69-76.

Arning, L., Haghikia, A., Taherzadeh-Fard, E., Saft, C., Andrich, J., Pula, B., Hoxtermann, S., Wieczorek, S., Akkad, D. A., Perrech, M., Gold, R., Epplen, J. T. and Chan, A. (2010). Mitochondrial haplogroup $\mathrm{H}$ correlates with ATP levels and age at onset in Huntington disease. J Mol Med.

Ballinger, S. W., Patterson, C., Knight-Lozano, C. A., Burow, D. L., Conklin, C. A., Hu, Z., Reuf, J., Horaist, C., Lebovitz, R., Hunter, G. C., McIntyre, K. and Runge, M. S. (2002). Mitochondrial integrity and function in atherogenesis. Circulation 106, 544-549.

Batalla, A., Alvarez, R., Reguero, J. R., Hevia, S., Iglesias-Cubero, G., Alvarez, V., Cortina, A., Gonzalez, P., Celada, M. M., Medina, A. and Coto, E. (2000). Synergistic effect between apolipoprotein $\mathrm{E}$ and angiotensinogen gene polymorphisms in the risk for early myocardial infarction. Clin Chem 46, 1910-1915.

Baudouin, S. V., Saunders, D., Tiangyou, W., Elson, J. L., Poynter, J., Pyle, A., Keers, S., Turnbull, D. M., Howell, N. and Chinnery, P. F. (2005). Mitochondrial DNA and survival after sepsis: a prospective study. Lancet 366, 2118-2121.

Belin, A.C., Bjork, B.F., Westerlund, M., Galter, D., Sydow, O., Lind, C., Pernold, K., Rosvall, L., Hakansson, A., Winblad, B., Nissbrandt, H., Graff, C. and Olson,, L. (2007). Association study of two genetic variants in mitochondrial transcription factor A (TFAM) in Alzheimer's and Parkinson's disease, Neurosci. Lett. 420, 257-262.

Benn, M., Schwartz, M., Nordestgaard, B. G. and Tybjaerg-Hansen, A. (2008). Mitochondrial haplogroups: ischemic cardiovascular disease, other diseases, mortality, and longevity in the general population. Circulation 117, 2492-2501.

Booker, L. M., Habermacher, G. M., Jessie, B. C., Sun, Q. C., Baumann, A. K., Amin, M., Lim, S. D., Fernandez-Golarz, C., Lyles, R. H., Brown, M. D., Marshall, F. F. and Petros, J. A. (2006). North American white mitochondrial haplogroups in prostate and renal cancer. J Urol 175, 468-472; discussion 472-463.

Castro, M. G., Huerta, C., Reguero, J. R., Soto, M. I., Domenech, E., Alvarez, V., GomezZaera, M., Nunes, V., Gonzalez, P., Corao, A. and Coto, E. (2006). Mitochondrial DNA haplogroups in Spanish patients with hypertrophic cardiomyopathy. Int J Cardiol 112, 202-206.

Di Lorenzo, C., Pierelli, F., Coppola, G., Grieco, G. S., Rengo, C., Ciccolella, M., Magis, D., Bolla, M., Casali, C., Santorelli, F. M. and Schoenen, J. (2009). Mitochondrial DNA 
haplogroups influence the therapeutic response to riboflavin in migraineurs. Neurology 72, 1588-1594.

DiMauro, S. and Schon, E. A. (2003). Mitochondrial respiratory-chain diseases. N Engl J Med 348, 2656-2668.

Ekstrand, M. I., Falkenberg, M., Rantanen, A., Park, C. B., Gaspari, M., Hultenby, K., Rustin, P., Gustafsson, C. M. and Larsson, N. G. (2004). Mitochondrial transcription factor A regulates mtDNA copy number in mammals. Hum Mol Genet 13, 935-944.

Gaweda-Walerych, K., Maruszak, A., Safranow, K., Bialecka, M., Klodowska-Duda, G., Czyzewski, K., Slawek, J., Rudzinska, M., Styczynska, M., Opala, G., Drozdzik, M., Canter, J. A., Barcikowska, M. and Zekanowski, C. (2008). Mitochondrial DNA haplogroups and subhaplogroups are associated with Parkinson's disease risk in a Polish PD cohort. J Neural Transm 115, 1521-1526.

Gonzalez, P., Garcia-Castro, M., Reguero, J. R., Batalla, A., Ordonez, A. G., Palop, R. L., Lozano, I., Montes, M., Alvarez, V. and Coto, E. (2006). The Pro279Leu variant in the transcription factor MEF2A is associated with myocardial infarction. J Med Genet 43, 167-169.

Hendrickson, S. L., Kingsley, L. A., Ruiz-Pesini, E., Poole, J. C., Jacobson, L. P., Palella, F. J., Bream, J. H., Wallace, D. C. and O'Brien, S. J. (2009). Mitochondrial DNA haplogroups influence lipoatrophy after highly active antiretroviral therapy. J Acquir Immune Defic Syndr 51, 111-116.

Herrnstadt, C. and Howell, N. (2004). An evolutionary perspective on pathogenic mtDNA mutations: haplogroup associations of clinical disorders. Mitochondrion 4, 791-798.

Huerta, C., Castro, M. G., Coto, E., Blazquez, M., Ribacoba, R., Guisasola, L. M., Salvador, C., Martinez, C., Lahoz, C. H. and Alvarez, V. (2005). Mitochondrial DNA polymorphisms and risk of Parkinson's disease in Spanish population. J Neurol Sci 236, 49-54.

Ikeuchi, M., Matsusaka, H., Kang, D., Matsushima, S., Ide, T., Kubota, T., Fujiwara, T., Hamasaki, N., Takeshita, A., Sunagawa, K. and Tsutsui, H. (2005). Overexpression of mitochondrial transcription factor a ameliorates mitochondrial deficiencies and cardiac failure after myocardial infarction. Circulation 112, 683-690.

Kanazawa, A., Nishio, Y., Kashiwagi, A., Inagaki, H., Kikkawa, R. and Horiike, K. (2002). Reduced activity of mtTFA decreases the transcription in mitochondria isolated from diabetic rat heart. Am J Physiol Endocrinol Metab 282, E778-785.

Kang, D., Kim, S. H. and Hamasaki, N. (2007). Mitochondrial transcription factor A (TFAM): roles in maintenance of mtDNA and cellular functions. Mitochondrion 7, 39-44.

Kathiresan, S., Voight, B. F., Purcell, S., Musunuru, K., Ardissino, D., Mannucci, P. M., Anand, S., Engert, J. C., Samani, N. J., Schunkert, H., Erdmann, J., Reilly, M. P., Rader, D. J., Morgan, T., Spertus, J. A., Stoll, M., Girelli, D., McKeown, P. P., Patterson, C. C., Siscovick, D. S., O'Donnell, C. J., Elosua, R., Peltonen, L., Salomaa, V., Schwartz, S. M., Melander, O., Altshuler, D., Merlini, P. A., Berzuini, C., Bernardinelli, L., Peyvandi, F., Tubaro, M., Celli, P., Ferrario, M., Fetiveau, R., Marziliano, N., Casari, G., Galli, M., Ribichini, F., Rossi, M., Bernardi, F., Zonzin, P., Piazza, A., Yee, J., Friedlander, Y., Marrugat, J., Lucas, G., Subirana, I., Sala, J., Ramos, R., Meigs, J. B., Williams, G., Nathan, D. M., MacRae, C. A., Havulinna, A. S., Berglund, G., Hirschhorn, J. N., Asselta, R., Duga, S., Spreafico, M., Daly, M. J., Nemesh, J., Korn, J. M., McCarroll, S. A., Surti, A., Guiducci, C., Gianniny, L., Mirel, D., Parkin, M., Burtt, N., Gabriel, S. B., Thompson, J. R., Braund, P. S., Wright, B. J., Balmforth, A. J., Ball, S. G., Hall, A. S., Linsel-Nitschke, P., Lieb, W., Ziegler, A., Konig, I., Hengstenberg, C., Fischer, M., Stark, K., Grosshennig, A., Preuss, M., Wichmann, H. E., Schreiber, S., Ouwehand, W., Deloukas, P., Scholz, M., Cambien, F., Li, M., Chen, Z., Wilensky, R., Matthai, W., Qasim, A., Hakonarson, H. H., Devaney, J., Burnett, M. S., Pichard, A. D., Kent, K. M., Satler, L., Lindsay, J. M., Waksman, R., Epstein, S. E., Scheffold, T., Berger, K., Huge, A., Martinelli, N., Olivieri, O., Corrocher, R., McKeown, P., Erdmann, E., Konig, I. R., Holm, H., Thorleifsson, G., Thorsteinsdottir, U., Stefansson, K., Do, R., Xie, C. and Siscovick, D. (2009). Genome-wide association of early-onset 
myocardial infarction with single nucleotide polymorphisms and copy number variants. Nat Genet 41, 334-341.

Kofler, B., Mueller, E. E., Eder, W., Stanger, O., Maier, R., Weger, M., Haas, A., Winker, R., Schmut, O., Paulweber, B., Iglseder, B., Renner, W., Wiesbauer, M., Aigner, I., Santic, D., Zimmermann, F. A., Mayr, J. A. and Sperl, W. (2009). Mitochondrial DNA haplogroup $\mathrm{T}$ is associated with coronary artery disease and diabetic retinopathy: a case control study. BMC Med Genet 10, 35.

Larsson, N. G., Wang, J., Wilhelmsson, H., Oldfors, A., Rustin, P., Lewandoski, M., Barsh, G. S. and Clayton, D. A. (1998). Mitochondrial transcription factor A is necessary for mtDNA maintenance and embryogenesis in mice. Nat Genet 18, 231-236.

Li, H., Wang, J., Wilhelmsson, H., Hansson, A., Thoren, P., Duffy, J., Rustin, P. and Larsson, N. G. (2000). Genetic modification of survival in tissue-specific knockout mice with mitochondrial cardiomyopathy. Proc Natl Acad Sci U S A 97, 3467-3472.

Madamanchi, N. R. and Runge, M. S. (2007). Mitochondrial dysfunction in atherosclerosis. Circ Res 100, 460-473.

Martinez-Redondo, D., Marcuello, A., Casajus, J. A., Ara, I., Dahmani, Y., Montoya, J., RuizPesini, E., Lopez-Perez, M. J. and Diez-Sanchez, C. (2010). Human mitochondrial haplogroup H: the highest VO2max consumer--is it a paradox? Mitochondrion 10, 102107.

Masayesva, B. G., Mambo, E., Taylor, R. J., Goloubeva, O. G., Zhou, S., Cohen, Y., Minhas, K., Koch, W., Sciubba, J., Alberg, A. J., Sidransky, D. and Califano, J. (2006). Mitochondrial DNA content increase in response to cigarette smoking. Cancer Epidemiol Biomarkers Prev 15, 19-24.

Miro, O., Alonso, J. R., Jarreta, D., Casademont, J., Urbano-Marquez, A. and Cardellach, F. (1999). Smoking disturbs mitochondrial respiratory chain function and enhances lipid peroxidation on human circulating lymphocytes. Carcinogenesis 20, 1331-1336.

Nishigaki, Y., Yamada, Y., Fuku, N., Matsuo, H., Segawa, T., Watanabe, S., Kato, K., Yokoi, K., Yamaguchi, S., Nozawa, Y. and Tanaka, M. (2007). Mitochondrial haplogroup N9b is protective against myocardial infarction in Japanese males. Hum Genet 120, 827-836.

Puddu, P., Puddu, G. M., Galletti, L., Cravero, E. and Muscari, A. (2005). Mitochondrial dysfunction as an initiating event in atherogenesis: a plausible hypothesis. Cardiology 103, 137-141.

Rosa, A., Fonseca, B. V., Krug, T., Manso, H., Gouveia, L., Albergaria, I., Gaspar, G., Correia, M., Viana-Baptista, M., Simoes, R. M., Pinto, A. N., Taipa, R., Ferreira, C., Fontes, J. R., Silva, M. R., Gabriel, J. P., Matos, I., Lopes, G., Ferro, J. M., Vicente, A. M. and Oliveira, S. A. (2008). Mitochondrial haplogroup H1 is protective for ischemic stroke in Portuguese patients. BMC Med Genet 9, 57.

Ross, R. (1995). Cell biology of atherosclerosis. Annu Rev Physiol 57, 791-804.

Ruiz-Pesini, E., Lapena, A. C., Diez-Sanchez, C., Perez-Martos, A., Montoya, J., Alvarez, E., Diaz, M., Urries, A., Montoro, L., Lopez-Perez, M. J. and Enriquez, J. A. (2000). Human mtDNA haplogroups associated with high or reduced spermatozoa motility. Am J Hum Genet 67, 682-696.

Ruiz-Pesini, E., Mishmar, D., Brandon, M., Procaccio, V. and Wallace, D. C. (2004). Effects of purifying and adaptive selection on regional variation in human mtDNA. Science 303, 223-226.

Russell, L. K., Mansfield, C. M., Lehman, J. J., Kovacs, A., Courtois, M., Saffitz, J. E., Medeiros, D. M., Valencik, M. L., McDonald, J. A. and Kelly, D. P. (2004). Cardiacspecific induction of the transcriptional coactivator peroxisome proliferator-activated receptor gamma coactivator-1alpha promotes mitochondrial biogenesis and reversible cardiomyopathy in a developmental stage-dependent manner. Circ Res 94, 525-533.

Sorescu, D. and Griendling, K. K. (2002). Reactive oxygen species, mitochondria, and $\mathrm{NAD}(\mathrm{P}) \mathrm{H}$ oxidases in the development and progression of heart failure. Congest Heart Fail 8, 132-140. 
Torroni, A., Huoponen, K., Francalacci, P., Petrozzi, M., Morelli, L., Scozzari, R., Obinu, D., Savontaus, M. L. and Wallace, D. C. (1996). Classification of European mtDNAs from an analysis of three European populations. Genetics 144, 1835-1850.

Tunstall-Pedoe, H., Kuulasmaa, K., Amouyel, P., Arveiler, D., Rajakangas, A. M. and Pajak, A. (1994). Myocardial infarction and coronary deaths in the World Health Organization MONICA Project. Registration procedures, event rates, and case-fatality rates in 38 populations from 21 countries in four continents. Circulation 90, 583-612.

Valdés, S., Botas, P., Delgado, E., Alvarez, F. and Cadórniga, F.D. (2007). Population-based incidence of type 2 diabetes in northern Spain: the Asturias Study. Diabetes Care. 2007 Sep;30(9):2258-63. Epub 2007 May 29.

van der Walt, J. M., Dementieva, Y. A., Martin, E. R., Scott, W. K., Nicodemus, K. K., Kroner, C. C., Welsh-Bohmer, K. A., Saunders, A. M., Roses, A. D., Small, G. W., Schmechel, D. E., Murali Doraiswamy, P., Gilbert, J. R., Haines, J. L., Vance, J. M. and PericakVance, M. A. (2004). Analysis of European mitochondrial haplogroups with Alzheimer disease risk. Neurosci Lett 365, 28-32.

van der Walt, J. M., Nicodemus, K. K., Martin, E. R., Scott, W. K., Nance, M. A., Watts, R. L., Hubble, J. P., Haines, J. L., Koller, W. C., Lyons, K., Pahwa, R., Stern, M. B., Colcher, A., Hiner, B. C., Jankovic, J., Ondo, W. G., Allen, F. H., Jr., Goetz, C. G., Small, G. W., Mastaglia, F., Stajich, J. M., McLaurin, A. C., Middleton, L. T., Scott, B. L., Schmechel, D. E., Pericak-Vance, M. A. and Vance, J. M. (2003). Mitochondrial polymorphisms significantly reduce the risk of Parkinson disease. Am J Hum Genet 72, 804-811.

Wang, J., Wilhelmsson, H., Graff, C., Li, H., Oldfors, A., Rustin, P., Bruning, J. C., Kahn, C. R., Clayton, D. A., Barsh, G. S., Thoren, P. and Larsson, N. G. (1999). Dilated cardiomyopathy and atrioventricular conduction blocks induced by heart-specific inactivation of mitochondrial DNA gene expression. Nat Genet 21, 133-137.

Gaweda-Walerych, K., Safranow, K., Maruszak, A., Bialecka, M., Klodowska-Duda, G., Czyzewski, K., Slawek, J., Rudzinska, M., Styczynska, M., Opala, G., Drozdzik, M., Kurzawski, M., Szczudlik, A., Canter, J.A., Barcikowska, M. and Zekanowski, C. 2010). Mitochondrial transcription factor A variants and the risk of Parkinson's disease. Neurosci Lett 469, 24-29. 
Suppl. Table 1. Primer sequences and PCR-RFLP conditions for the $10 \mathrm{mtDNA}$ SNPs that defined the nine major haplogroups, and the A3010G that divided haplogroup $\mathrm{H}$ into $\mathrm{H} 1$ and non-H1.

\begin{tabular}{|c|c|c|c|c|}
\hline Polymorphism & $\begin{array}{l}\text { PCR - Primers } \\
\text { Forward/Reverse }\end{array}$ & $\begin{array}{l}\text { Annealing } \\
\left({ }^{\circ} \mathrm{C}\right)\end{array}$ & $\begin{array}{l}\text { Restriction } \\
\text { enzyme }\end{array}$ & $\begin{array}{l}\text { Allele sizes } \\
\text { (base pairs) }\end{array}$ \\
\hline G1719A & $\begin{array}{l}\text { TCACCCTCCTCAAGTATACTTCA } \\
\text { ATTTGGGTAAATGGTTTGGC }\end{array}$ & 58 & DdeI & $\begin{array}{l}\text { G: } 148+79+23 \\
\text { A: } 148+102\end{array}$ \\
\hline G4580A & $\begin{array}{l}\text { ACCTATCACACCCCATCCTAAA } \\
\text { AGGATTATGGATGCGGTT }\end{array}$ & 60 & NheI & $\begin{array}{l}\text { G:200+100 } \\
\text { A:300 }\end{array}$ \\
\hline C7028T & $\begin{array}{l}\text { AATGATCTGCTGCAGTGCTC } \\
\text { TCCGGATAGGCCGAGAA } \\
\end{array}$ & 60 & AluI & $\begin{array}{l}\text { C: } 156+152 \\
\mathrm{~T}: 152+126+30\end{array}$ \\
\hline G8251A & $\begin{array}{l}\text { ATGCAATTCCCGGACGTCT } \\
\text { TTCACTGTAAAGAGGTGTTGGTTCT }\end{array}$ & 54 & HaeIII & $\begin{array}{l}\text { G: } 149+114 \\
A: 263\end{array}$ \\
\hline G9055A & $\begin{array}{l}\text { CCCATACTAGTTATTATCGA } \\
\text { TAGGGGTCATGGGCGGGTT }\end{array}$ & 58 & HhaI & $\begin{array}{l}\text { G: } 185+115 \\
\text { A:300 }\end{array}$ \\
\hline A10398G & $\begin{array}{l}\text { AGCCCTACAAACAACTAACCTGC } \\
\text { AGTAGGGAGGATATGAGGTGTGAG }\end{array}$ & 53 & DdeI & $\begin{array}{l}\text { A: } 205+68 \\
\text { G: } 167+68+38\end{array}$ \\
\hline A12308G & $\begin{array}{l}\text { ATTTACCGAGAAAGCTCACAAG } \\
\text { TTTTATTTGGAGTTGCACCACGAT }\end{array}$ & 60 & HinfI & $\begin{array}{l}\text { A: } 134 \\
\text { G: } 109+25\end{array}$ \\
\hline G13368A & $\begin{array}{l}\text { TAGCCTTCTCCACTTCAAGTC } \\
\text { AGAAACCTGTAGGAAAGGTATT }\end{array}$ & 60 & Sau96I & $\begin{array}{l}\text { G: } 137+127 \\
\text { A:264 }\end{array}$ \\
\hline G13708A & $\begin{array}{l}\text { CCTCACAGGTTTCTACTCCAAA } \\
\text { AAGTCCTAGGAAAGTGACAGC }\end{array}$ & 57 & Fnu4HI & $\begin{array}{l}\text { G: } 197+121 \\
\text { A:318 }\end{array}$ \\
\hline G16391A & $\begin{array}{l}\text { AACCTACCCACCCTTAACAG } \\
\text { CATCGTGATGTCTTATTTAAGGG }\end{array}$ & 60 & Sau96I & $\begin{array}{l}\text { G:114+104+65 } \\
\text { A: } 172+114\end{array}$ \\
\hline A3010G & $\begin{array}{l}\text { TGTTGGATCAGGACATCGC } \\
\text { CAATGAGGAGTAGGAGGTTG }\end{array}$ & 60 & BstUI & $\begin{array}{l}\text { A:376 } \\
\text { G:357 }\end{array}$ \\
\hline
\end{tabular}


Suppl. Table 2. Definition of the 9 mitochondrial haplogroups based on the 10 SNPs.

\begin{tabular}{|c|c|c|c|c|c|c|c|c|c|c|}
\hline $\begin{array}{l}\text { HAPLO } \\
\text { GROUP }\end{array}$ & G1719A & G4580A & C7028T & G8251A & G9055A & A10398G & A12308G & G13368A & G13708A & G16391A \\
\hline H & G & G & C & G & G & A & A & G & G & G \\
\hline I & A & G & T & A & G & G & A & G & G & A \\
\hline J & G & G & T & G & G & G & A & G & A & G \\
\hline K & G & G & T & G & A & G & G & G & G & G \\
\hline T & G & G & T & G & G & A & A & A & G & G \\
\hline U & G & G & T & G & G & A & G & G & G & G \\
\hline V & G & A & T & G & G & A & A & G & G & G \\
\hline W & G & G & T & A & G & A & A & G & G & G \\
\hline X & A & G & T & G & G & A & A & G & G & G \\
\hline
\end{tabular}


Suppl. Table 3. Primers and PCR conditions to amplify the TFAM coding exons. Primer sequences were designated from the TFAM UCSC reference sequence NM003201 (http://genome.ucsc.edu)

\begin{tabular}{|c|c|c|c|}
\hline Exon & PCR-Primers & $\begin{array}{c}\text { PCR- } \\
\text { annealing } \\
\left({ }^{\circ} \mathrm{C}\right)\end{array}$ & $\begin{array}{l}\text { Size } \\
\text { (bp) }\end{array}$ \\
\hline 1 & $\begin{array}{l}\text { CCCCGCCCCCATCTTACCGA } \\
\text { GACGTCCTGGGCCCTGCTG }\end{array}$ & 61 & 326 \\
\hline 2 & $\begin{array}{c}\text { GGGATCTGTGTTCATATACATG } \\
\text { CAACATTGGTATTTAACTGCTTA }\end{array}$ & 53 & 270 \\
\hline 3 & $\begin{array}{l}\text { TAATCCTGAGAGGTAAAATTGTG } \\
\text { ATTGTCCTAACTGCAGAAT }\end{array}$ & 53 & 180 \\
\hline 4 & $\begin{array}{c}\text { GGTTTGTTGACTTACTTGGG } \\
\text { TTATATAAATCTCAATTCTTTACC }\end{array}$ & 53 & 238 \\
\hline 5 & $\begin{array}{c}\text { GTCTCATGGAGGTTAACACTA } \\
\text { CCTGACACATGGCACTCTA }\end{array}$ & 55 & 220 \\
\hline 6 & $\begin{array}{l}\text { TAAAGGTCACTGAAGTCCCC } \\
\text { GCCCTAATACATTCTCCACAG }\end{array}$ & 58 & 178 \\
\hline 7 & $\begin{array}{c}\text { GCATTCCAGAAATTAATTGC } \\
\text { CGATAGCTTCAGGTATTGAGAC }\end{array}$ & 53 & 337 \\
\hline
\end{tabular}


Suppl. Table 4. Main characteristics of the index cohort, haplogroup H vs. non-H.

\section{Patients}

\begin{tabular}{|c|c|c|c|c|c|c|c|c|}
\hline Haplo. & Age & Smokers & $\begin{array}{l}\text { Cholest. } \\
\text { (mg/dl) }\end{array}$ & $\begin{array}{c}\mathrm{HDL} \\
(\mathrm{mg} / \mathrm{dl})\end{array}$ & $\begin{array}{c}\mathrm{TG} \\
(\mathrm{mg} / \mathrm{dl})\end{array}$ & Diabetes & Hypertensives & $\begin{array}{c}\text { Diseased } \\
\text { Vessels }\end{array}$ \\
\hline \multirow{2}{*}{$\begin{array}{c}\mathrm{H} \\
(\mathrm{n}=252)\end{array}$} & \multirow{2}{*}{$42 \pm 6$} & Yes:252(97\%) & \multirow{2}{*}{$210 \pm 46$} & \multirow{2}{*}{$33 \pm 8$} & \multirow{2}{*}{$185 \pm 95$} & \multirow{2}{*}{$\begin{array}{l}\text { Yes: } 11 \% \\
\text { No: } 89 \%\end{array}$} & \multirow{2}{*}{$\begin{array}{l}\text { Yes: } 36 \% \\
\text { No: } 64 \%\end{array}$} & 1: $49 \%$ \\
\hline & & No: $8(3 \%)$ & & & & & & $>1: 51 \%$ \\
\hline \multirow{2}{*}{$\begin{array}{c}\text { No H } \\
(\mathrm{n}=248)\end{array}$} & \multirow{2}{*}{$43 \pm 5$} & Yes:243 (98\%) & \multirow{2}{*}{$223 \pm 41$} & \multirow{2}{*}{$34 \pm 9$} & \multirow{2}{*}{$\begin{array}{c}181 \pm 12 \\
0\end{array}$} & \multirow{2}{*}{$\begin{array}{l}\text { Yes: } 11 \% \\
\text { No: } 89 \%\end{array}$} & \multirow{2}{*}{$\begin{array}{l}\text { Yes: } 34 \% \\
\text { No: } 66 \%\end{array}$} & 1: $43 \%$ \\
\hline & & No: $5(2 \%)$ & & & & & & $>1: 57 \%$ \\
\hline
\end{tabular}

\section{Controls}

\begin{tabular}{|c|c|c|c|c|c|c|}
\hline Haplo. & Age & Smokers & Cholest. & HDL & TG & Hypertensives \\
\hline $\begin{array}{c}\text { H } \\
(\mathrm{n}=202)\end{array}$ & $43 \pm 9$ & $\begin{array}{c}\text { Yes:99 (49\%) } \\
\text { No:103 (51\% }\end{array}$ & $207 \pm 39$ & $54 \pm 14$ & $111 \pm 74$ & $\begin{array}{l}\text { Yes: } 10 \% \\
\text { No: } 90 \%\end{array}$ \\
\hline $\begin{array}{c}\text { No H } \\
(\mathrm{n}=298)\end{array}$ & $44 \pm 9$ & $\begin{array}{c}\text { Yes:168 (56\%) } \\
\text { No:130 (44\%) }\end{array}$ & $197 \pm 39$ & $54 \pm 11$ & $121 \pm 112$ & $\begin{array}{l}\text { Yes: } 12 \% \\
\text { No: } 88 \%\end{array}$ \\
\hline
\end{tabular}


Suppl. Table 5. Distribution of the TFAM genotypes in patients and controls, haplogroup $\mathrm{H}$ vs. non $\mathrm{H}$ (parenthesis, \%).

\begin{tabular}{|c|c|c|c|c|c|}
\hline & & Patients $H$ & $\begin{array}{c}\text { Patients } \\
\text { Non-H }\end{array}$ & Controls H & $\begin{array}{c}\text { Controls } \\
\text { non-H }\end{array}$ \\
\hline $\begin{array}{c}\text { rs1937 } \\
+35 \mathrm{C} / \mathrm{G} \\
(\mathrm{S} 12 \mathrm{~T})\end{array}$ & $\begin{array}{l}\text { GG } \\
\text { GC } \\
\text { CC }\end{array}$ & $\begin{array}{c}175(88) \\
23(11) \\
2(1)\end{array}$ & $\begin{array}{c}177(89) \\
21(10) \\
2(1)\end{array}$ & $\begin{array}{c}163(91) \\
16(9) \\
1(<1)\end{array}$ & $\begin{array}{c}244(90) \\
24(10) \\
2(<1)\end{array}$ \\
\hline $\begin{array}{c}\text { rs17710934 } \\
+183 \mathrm{~T} / \mathrm{C} \\
(\mathrm{S} 61 \mathrm{~S}) \\
\end{array}$ & $\begin{array}{l}\text { TT } \\
\text { TC } \\
\text { CC }\end{array}$ & $\begin{array}{c}121(96) \\
4(4) \\
0 \\
\end{array}$ & $\begin{array}{c}120(95) \\
5(5) \\
0 \\
\end{array}$ & $\begin{array}{c}94(93) \\
7(7) \\
0 \\
\end{array}$ & $\begin{array}{c}131(88) \\
18(12) \\
0 \\
\end{array}$ \\
\hline $\begin{array}{c}\text { rs34084383 } \\
\text { IVS3-13 } \\
\text { del/insT } \\
\end{array}$ & $\begin{array}{l}\text { INS/INS } \\
\text { INS/DEL } \\
\text { DEL/DEL }\end{array}$ & $\begin{array}{c}2(1) \\
33(27) \\
90(72)\end{array}$ & $\begin{array}{c}0 \\
32(26) \\
93(74)\end{array}$ & $\begin{array}{c}2(2) \\
29(29) \\
70(69)\end{array}$ & $\begin{array}{c}3(2) \\
46(31) \\
100(67)\end{array}$ \\
\hline $\begin{array}{l}\text { rs41283688 } \\
\text { IVS6 +11G/A }\end{array}$ & $\begin{array}{l}\text { GG } \\
\text { GA } \\
\text { AA }\end{array}$ & $\begin{array}{c}109(87) \\
14(11) \\
2(2)\end{array}$ & $\begin{array}{c}106(85) \\
18(14) \\
1(1)\end{array}$ & $\begin{array}{c}81(80) \\
19(19)) \\
1(1)\end{array}$ & $\begin{array}{c}124(83) \\
24(16) \\
1(1)\end{array}$ \\
\hline
\end{tabular}




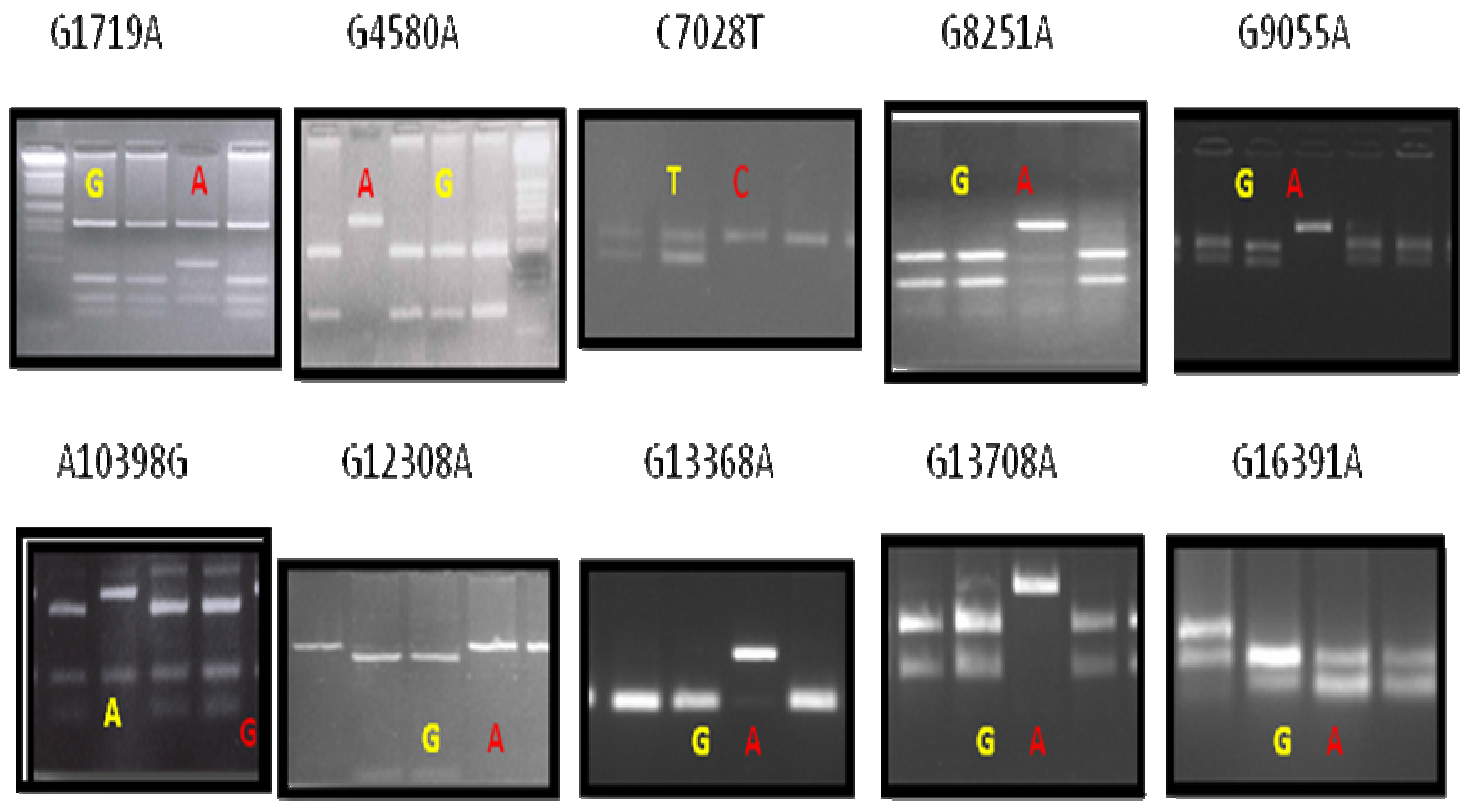

Supplementary figure 1. Restriction fragment sites of the differente alleles at the 10 mitochondrial polymorphisms. 


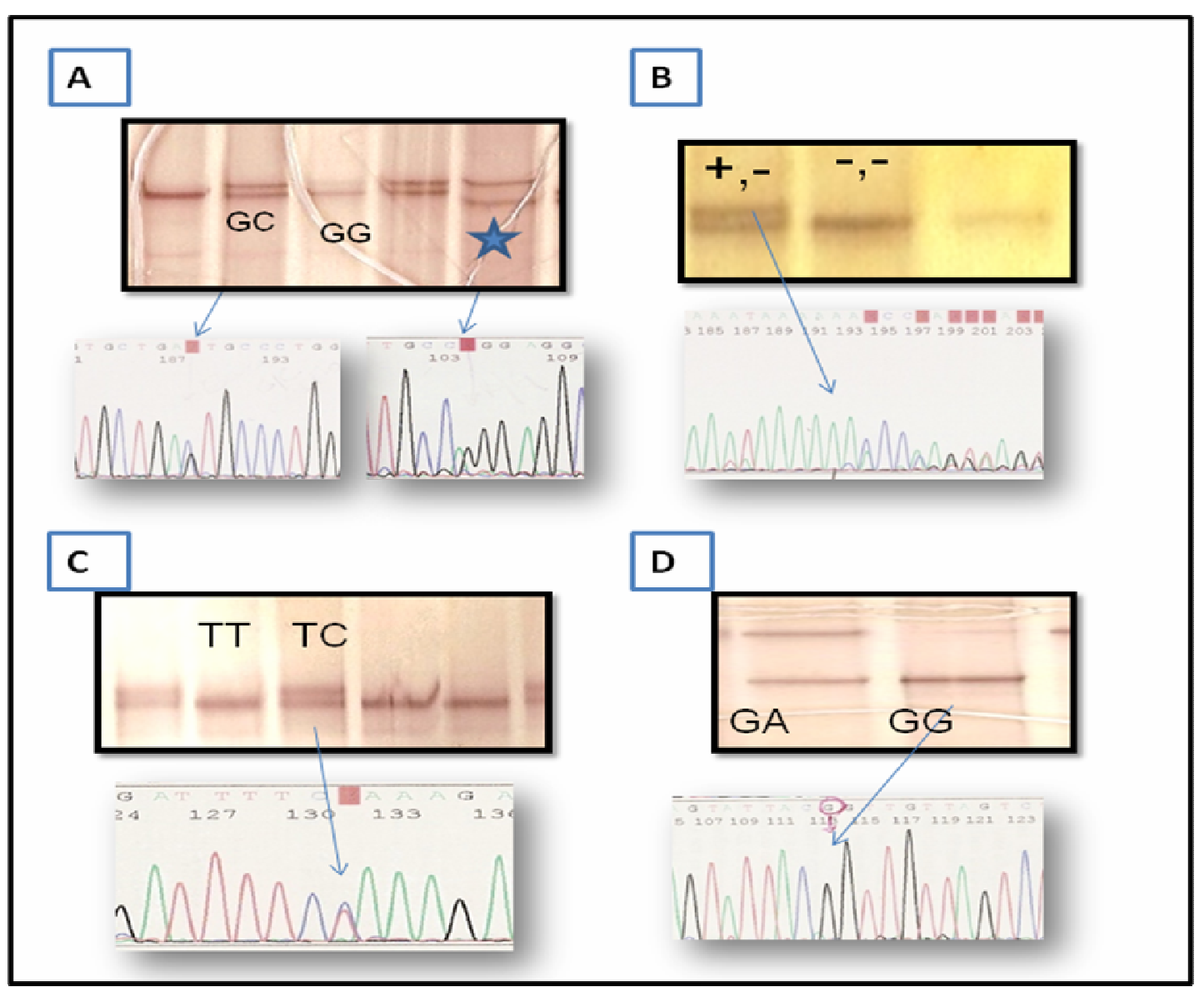

Supplementary figure 2. SSCA and sequence of the different genotypes at the four TFAM polymorphisms: A, rs1937; B, rs34084383; C, rs17710934; D, rs41283688. 